\author{
Cracow Indological Studies \\ Vol. XXII, No. 2 (2020), pp. 1-15 \\ https://doi.org/10.12797/CIS.22.2020.02.01
}

Lidia Wojtczak (D)

lw24@soas.ac.uk

(SOAS, University of London, United Kingdom)

\title{
The Winding Ways of Poetry: Ratnaśrījñāna on Dạ̣ḍin's mārgas
}

SUMMARY: One of the earliest Sanskrit poeticians, Dandin, dedicates an entire chapter of his Kā vyādarśa to the investigation of mārgas or the 'ways' of poetry. These are based on adaptable configurations of poetic qualities and faults and, although there seems to be an infinite number of 'ways', Daṇ̣in characterises only two, Vaidarbha and Gauḍiya. In this paper, I show how the earliest known commentator of the Kāvyādarśa, Ratnaśrījñāna, uses philosophical discussions and archetypes to expand on Dandin's rather cursory engagement with the methodology of the 'ways' to create a truly śāstric schema.

KEYWORDS: mārga, rīti, Daṇụin, Kāvyādarśa, Ratnaśrīinñāna, sādrșya

Between the ninth and the eleventh century of the Common Era Sanskrit poetics and aesthetic thought were experiencing perhaps their most effervescent moment with the Kashmir valley at the epicentre of the new wave. Questions of meaning, suggestion and understanding took centre stage as the rasa-dhvani theory of Ānandavardhana and his commentator, Abhinavagupta, finally emerged more or less victorious in the debate. Yet, equally important as the intricacies of the dominant theory of literary expression are the turbulent discussions, vehement refutations, theoretical experiments and the dead-end avenues that served as the intellectual backdrop against which dhvani was able to develop and with which it had to contend. They allow us to follow 
the dynamics of interdisciplinary knowledge production more generally as a alamkärikas adapted their theories in response to scholarly interactions of poetics with other fields.

In this paper I focus on a theory of literary analysis which undoubtedly could not stand the test of time, practice, and of the śāstric requirements for systematicity and instruction, ${ }^{1}$ that is the theory of riti or mārga - the 'modes' or 'ways' of poetry. The emphasis will not be on the 'ways' themselves but on how they were presented in Ratnaśrījñāna's Ratnaśrîțîkā, the earliest extant commentary on Daṇ̣in's Kāvyyādarśa (KĀ).

The best-known expounder of rit i is the ninth-century Kashmiri, Vāmana, author of the Kāvyālamkārasūtras and their autocommentarial Vrtti (KASV). While his ritti-centred theory proposed a fresh way of looking at poetic language, unfortunately for Vāmana, it was not able to withstand closer scrutiny, a fact which was not helped by his laconic style or confusing choice of exemplifying verses. The main thrust of Vāmana's argument is that rìt $i$, as the 'soul' of poetry, is innate $(\text { nitya })^{2}$ whereas alamkāras, such as metaphor or alliteration, are ornaments that serve to enhance the gunas and therefore elective. The rittis (there are three in Vāmana's system: Vaidarbhī, Gauḍīyā and Pāñcālī) are characterised as being a special arrangement of gunas, or poetic qualities, ${ }^{3}$ and classified in a hierarchy with Vaidarbhi at the apex on account of it possessing all the gunas, while the other two possess

See Tubb 2008 on the quest to establish alamkāraśāstra as a prescriptive system and a 'real' śāstric discipline. The śāstra-nirdeśa which comprises the second chapter of Rājaśekhara's Kāvyamìmāmsāa is a particularly poignant example.

2 kāvya-śobhāyāh kartāro dharmā gunāh || KASV 3.1.1 || tad-atiśaya-hetavas tv alamkārāh || 3.1.2 || pürve nityāh || 3.1.3 || "Gunas are the qualities which make a poem beautiful. Alamkāras, on the other hand, are what enhances (the beauty). The first (i.e. the gunas) are permanent". Note the resonance between Vāmana's sūtra 3.1.1 and Daṇ̣in's KĀ verse 2.1ab: kāvya-śobhākārānn dharmān alaṃkārān pracakṣate. All citations from the $K \bar{A}$ are from Dimitrov 2002.

${ }^{3}$ rītir ātma kāvyasya $\|$ rîtir nāmeyam àtmā kāvyasya | śarīrasyeveti vākya-

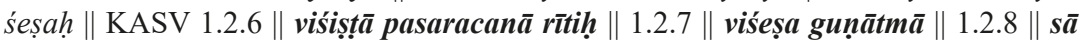

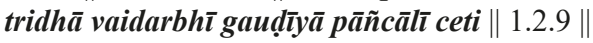


fewer. Vāmana does not seem to acknowledge the difficulties posed by his postulation that gunas, which are all fundamental and make up the stuff of poetry, can also be chosen from at will depending on the rit i employed by the author. ${ }^{4}$

While giving special attention to gunas is, in itself, not particularly revolutionary, it is Vāmana's empirical approach to poetic qualities that jars in combination with his attempt at creating a formal sütra and a structural model of poetic language. His definitions of the gunas are founded, at their core, on what seems to be a subjective and reception-based type of stylistic analysis. Gerow suggests that Vāmana condemned himself to unavoidable failure at the onset since, "gunas, like the doșas, may help us distinguish good poetry from bad poetry, but will never help us conceive poetry" (1971: 35), the latter being, according to him, the main interest of the alamkārikas.

The majority of poeticians succeeding Vāmana did not engage significantly with the ritis and while the 'ways' never quite seemed to disappear, they were often relegated to either a type of alliteration or to a mode of compounding. ${ }^{5}$ In other words, over time, they were slotted neatly into categories of form rather than of meaning. ${ }^{6}$

4 On the problems with interpreting Vāmana's definition of the (śabda-)gunas, Tubb (1985: 567-568) writes: “... Vāmana's comments (...) are frustratingly difficult to interpret. Aside from the general problem of the subjective nature of much of the analysis of phonetic texture, there are particular problems with matching Vāmana's definitions with his illustrations. (...) he does not explain any of his illustrations in detail. (...) The use of a single example for several difference qualities adds to the difficult of determining the precise characteristics of each guna."

5 Hence the inappropriateness of referring to a ' $r i \bar{t} i$ school'. See McCrea 2008: $37 \mathrm{ff}$. on the topic of 'schools' of poetics. Whether the 'ways' were retained as a category because of what Pollock calls the "habit of sedimentation" (2003: 43) within Sanskritic intellectual history or because they actually started playing a productive role in the system is another matter.

6 For instance, Rudrața ( $9^{\text {th }}$ c. CE, Kashmir), a contemporary of Vāmana, says that the categorisation of Pāñcālī, Lāṭiyā and Gaudịyā is based on the number of words in the compounds used: Pāñcālī allows for the compounding of two to three words, Lāṭiyā has from five to seven and as many words as possible are compounded in the Gaudīyā rìti. The only mode in which compounds are not employed is Vaidarbhī 
Vāmana may have been a trailblazer who tried to revolutionise poetics by suggesting an empirical mode of analysis, but he was not, of course, the first to suggest that there is a place in literary theory for the 'ways' conceived as constellations of gunas. Dandin dedicated most of the first chapter of his seminal $\mathrm{K} \bar{A}$ to mārga-vibhāga, or the 'classification of the ways'. Dandin's märgas - he names only two, Vaidarbha and Gauḍiya - are based on guṇas founded on perhaps more formal and largely phonetic grounds (although qualities like samādhi, which seems to be the quality of figurative expression, pose a more complex conundrum). At the heart of Daṇdin's success, however, seems to be the fact that his gunas are a part of the larger category of 'ornaments' and their role is to "make poetry beautiful". ' Although Daṇin does place significant weight on the gunas, he does not state as bluntly as Vāmana that they are the necessary constituents of all poetry and in doing so, he manages to avoid many of the criticisms that challenge Vāmana's version of the theory. ${ }^{8}$

\section{Ratnaśrījñāna on the mārgas}

According to Dragomir Dimitrov (2016: 51ff.), the Sinhalese polymath and Buddhist monk, Ratnaśrījñāna, composed his Ratnaśrịtīikā, the earliest extant $\mathrm{KA}$ commentary, in $952 \mathrm{CE}$, at the court of 'Tunga Dharmāvaloka', a Rāṣtrakūṭa vassal of the Pāla king Rājyapāla. ${ }^{9}$ In what follows I will focus on how Ratnaśrījñāna structured his

(Rudrața's Kāvyālaṃkāra 2.3-6). There are, of course, notable exceptions to this trend of demoting the 'ways', including Rājaśekhara's Kāvyamīmāmsāa, both of Bhoja's treatises and Kuntaka's Vakroktijivita.

$\mathrm{KA}$ Ā 2.1ab: kāvya-śobhākārān dharmān alaṃkārān pracakșate|

8 That is not to say that Dandin's understanding of gunas is very clear-see Lahiri 1937: 59ff. for an in-depth discussion on this topic.

9 This dating is based both on verses and the colophon from the Ratnaśrițīk and the so-called Bodh Gayā inscription. The crucial passages in Dimitrov's edition and translation can be found in Dimitrov 2016: 68. See also Pollock 2005-he reaches a similar conclusion on the dating of the commentary and places it in $955 \mathrm{CE}$, 
introduction to the 'ways' of literature, reflecting on the conceptualisation of poetics as a philosophical discipline.

The most revolutionary moment for alamkāraśāstra was undoubtedly ushered in with the paradigm shift first proposed by Lawrence McCrea in his seminal study of Kashmiri poetics (2008). One of the key points that McCrea makes is that the transformation of poetics in midninth century Kashmir occurred when Ānandavardhana reached for the teleological hermeneutics of Mīmāṃsā to create new tools for the analysis of poetic language. Yet philosophy had quite clearly formed one of the foundations of poetic inquiry since the inception of alamkāraśästra. For instance, the treatment of many of the semantic gunas and doșas was most likely to have been inspired by the discussions present in Nyāya texts and in the context of philosophical debate. ${ }^{10}$

Notably, Bhāmaha's system of poetic faults relies heavily on requirements of logical accuracy and the author devotes an entire section of his Kāvyālamkāra (chapter 5) to the faults of poetry caused by the absence of pratijñ $\bar{a}$, hetu, etc.- - referring perhaps to the syllogism of correct inference - and says that he will rely on Nyāya to discuss the matter. He does not take this formal introduction of philosophy into poetics for granted, however, and notes that fools (amedhas) are frightened of the śástras because they are difficult to understand.

but he sees 'Tunga' not as a vassal but potentially as Kṛṣna III Rāșțakūṭa himself. The second oldest extant KĀ commentary is the Śrutānupāilin̄ of Vādijanghāla, who, as Pollock (2006: 344) has stipulated, is "to be identified with Vādighanghāla Bhațta described in a tenth-century Ganga grant", and was a scholar at the court of Kṛnna III Rāștrakūta (939-968). His commentary was therefore composed at a very similar time and place to Rantaśrīiñāna's. The third oldest extant commentary available to us is that of Tarunavācaspati, and it was also written in the Deccan, "at the Hoysala court in the late twelfth century" (Pollock 2006: 344). Perhaps this affinity of Deccani scholars for Danḍin's text stemmed from his appreciation of the Vaidarbha mārga, or 'the Southern way'.

10 See especially Raghavan's discussion on doṣas in Raghavan 1978: $210 \mathrm{ff}$. 
He promises to treat his readers only to the tiniest and most relevant sliver (lava) of hetu-nyāya. ${ }^{11}$

Bhāmaha's affinity with philosophy does not seem to have been matched by that of Dandin. However, as we shall see, Daṇ̣in's commentator, Ratnaśrījñāna, decides to bring logic into sharp relief in his treatment of the 'ways' in the Ratnaśrițīka . Daṇin's theory is contingent on the premise that the gunas can be arranged at will and in varying concentration. Consequently, there is practically an infinite number of 'ways'. This fluidity and optionality of gunas frames the entire mārgavibhäga. The multitude of subtly different 'ways' is established in the first verse of the section, 1.40, and the point is reinforced in the closing verses of Chapter One of the KA $\bar{A}$. After illustrating each guna and connecting it either to Vaidarbha mārga or Gauḍīya mārga, or both, Daṇụin concludes the section with verse 1.101 in which he posits that these two 'ways' are perhaps superordinate categories which may be further infinitely subdivided into as many 'sub-ways' as there are individual poets. Verse 1.102 is a creative illustration of the elusiveness of difference:

asty aneko girām mārgah sūkșma-bhedah paras-param |

tatra vaidarbha-gauḍ̄yau varṇyete prasphuțāntarau || KĀ 1.40

iti mārga-dvayam bhinnam tat-svarūpa-nirūpaṇāt |

tad-bhedās tu na śakyante vaktum prati-kavi-sthitāh || KĀ 1.101

ikșu-kșìra-gud̄ādīnām mādhuryasyāntaram mahat |

tathāpi na tad ākhyātum sarasvatyāpi śakyate || KĀ 1.102

There are many 'ways' of poetry; they are mutually very subtly distinguished. Among these the Vaidarbha and the Gaudieya ways, which are very different from each other, will be described.

11 Kāvyālamkiāra 5.1-2. The discussion that follows becomes quite opaque because Bhāmaha moves away from the sense of pratijñ $\bar{a}$ as 'thesis' (5.13-20) and starts treating it in the sense of 'vow' (examples in 5.36ff.). He does this explicitly and explains that in poetry these concepts have different definitions than in Nyāya (5.30-35). 
And so, the two ways of literature are distinguished based an investigation of their characteristics. Their [sub-]divisions are determined individually, they reside within each poet and cannot be described.

There is a great difference in the sweetness of sugarcane, milk, sugar and other such things but even Sarasvatī, Goddess of Speech, cannot put this difference into words.

Dandin devotes over 60 verses to describing how the presence, absence or intensity of a particular guna characterises these two, extremely different mārgas only to conclude that there are actually more 'ways' than can be listed since every individual poet will compose in a slightly different mode. In this sense, by referring to the 'ways' as the result of subjective authorial choices, Danḍin's theory seems far removed from the generally accepted remit of the formalist ālamkārikas.

One of the key points of investigation is the character of the 'difference' introduced in verse 1.40 which is further bolstered in the following verses, where Dandin famously states that the ten gunas constitute the life (prāna) of the Vaidarbha way, whereas Gaudīya usually (prāyah) possesses "their opposite" (eșām viparyayah). Ratnaśrījñāna starts his commentary on the mārga-vibhāga with a penetrating analysis hinged on 'thinking through' the ideas of difference and similarity put forward by Dandin in verse 1.40 :

There are many methods of composition - by many, we mean that they are different and belong to different 'universal kinds' (jāti) and they are divided based on the division of places like the North, etc. Are these absolutely dissimilar? (ekānta-visadriśah) NoDandin says that they are "mutually very subtly distinguished" (sūkșma-bhedah paras-param) (...) This general rule (utsarga) states that they are similar in as much as they belong to different kinds, like a cow and a gayal, etc. The restricting rule (apavāda) is in the words: "Among these, the Vaidarbha and the Gaudiya ways, which are very different from each other, will be described".

Vidarbha is the 'South' - the name of one place [i.e. Vidarbha] being used as a synecdoche (upalakșanatvāt) standing for the entire 
direction. The way of the Southerners is the Vaidarbha way. The Gaudas are the Easterners and theirs is the Gaudinya way. These two ways are clearly distinct (tau mārgau prasphuțau). Though they belong to different kinds, the other [unnamed] ways are similar to the Vaidarbha style, like the gayal is [similar to] the cow. The Gaudiya way is completely dissimilar [to these], like a camel is [dissimilar] to a cow. The division into individual (vyakti) [ways] is infinite and [they] reside in individual poets, therefore it is not possible to list them all here one by one. For [Dandin] says:

Their [sub-]divisions are determined individually, they reside within each poet and cannot be described. [KĀ 1.101cd]

If that is the case, then what is the point [of the discussion]? [Danḍin] says he will describe, i.e. distinguish between, two because it is easy to distinguish between two ways which are clearly distinct. The remaining ways will not be spoken of since they resemble the Vaidarbha way. ${ }^{12}$

Ratnaśrījñāna goes on to reject Bhāmaha's famous repudiation of 'ways' as a viable theoretical category (citing Kāvyālaṃkāra 1.31-32). He dissects Bhāmaha's assertion that only fools (amedhas) reach for the categories of Vaidarbha and Gaudīya as a means of qualifying poetry. Ratnaśrījñāna proves, in the most basic of ways, that there is clearly a material difference between things that come from the North and from the South and therefore questions Bhāmaha's reasons for making this statement (tataś ca vāstavīyam nānātā katham amedhasām). In fact, says Ratnaśrījñāna, what Bhāmaha is referring to are people who are suffering from a warped perception (viparita-driś) but even those who are wise (sumedhas) may suffer from delusions such as the one that there is more than one moon. ${ }^{13}$

12 For the Sanskrit text, see Thakur-Jha 1957: 27ff. This edition of the text has been digitised by Andrew Ollett and published on SARIT: https://sarit.indology.info/ ratnasritika-dn.xml?view $=\operatorname{div}(27.08 .2020)$. This edition was prepared on the basis of a single surviving manuscript and contains no critical apparatus.

13 A common example of perceptual illusion occurring when someone who suffers from an eye-disease called timira or is intoxicated sees two moons in the night 
He then moves on to the other key problem of the 'ways' - the fact that it is possible to compose in any way one desires, irrespective of one's location or birthplace. He is not too perturbed by the matter, however, and simply states that things have a way of travelling and in the same way as one may find sandalwood in the East, although it is indigenous to the South, so, too, the ways of poetry may find themselves being used by poets to whom they are not indigenous.

\section{What makes a märga? On cows, gayals, and camels}

There are a number of issues at hand in these passages, but I will focus on the notions of similarity (sādriśya) and analogy (upamāna). Ratnaśrījñāna's discussion of difference (or sameness) is likely being prompted by Nyāya considerations - more specifically, by the discussion started under Nyâyasütra (NS) $1.1 .6^{14}$ on the definition of upamāna, analogical reasoning, as one of the four accepted pramānas, or instruments of valid cognition, which is further developed in NS 2.1.44-48. In the Nyāyasūtrabhāsya (NBh) under NS 1.1.6, Vātsyāyana provides the archetypal example of analogical reasoning which is at the core of Ratnaśrījñ̄āna's argument- "a gayal is like a cow" (yathā gaur evam gavaya iti).

This statement can serve as a valid means of cognition, explains the NBh, because a person who hears it but has never seen a gayal, may enter a jungle and, upon encountering an unknown but clearly bovine creature there, will correctly come to know that the animal in front of them is in fact the gayal on account of its possessing qualities similar to that of a well-known cow. Accordingly, in the alamkāraśāstra example, Vaidarbha and all the unnamed 'ways' are similar to one

sky. It is one of the stock examples in the discussion of direct perception as a means of veridical cognition (e.g. Vasubandhu, Vimśatikā, 1).

14 prasiddha-sādharmyāt sādhya-sādhanam upamānam (NS. 1.1.6): “Analogical reasoning is (that source of cognition) which accomplishes its goal on the basis of (subject and object) possessing common properties." 
another like a cow and a gayal, in the sense that once we know the characteristics (dharma) of the Vaidarbha 'way', we will be able to recognise the other 'ways' based on them possessing similar characteristics. Whereas in the Nyāya analogy, we will observe horns, four hooves and a dewlap in the encountered animal, in poetry we will notice the presence and/or the conspicuousness of the guṇas as described by Daṇin.

Ratnaśrījñāna's judgement that the 'ways' are similar although they belong to different 'universal kinds' (vijātīyatve 'pi sadrśso 'sti mārgah) further calls to mind the examination of sädrsya given in the context of analogical reasoning by Kumārila in his Ślokavārttika (Upamāna, 18) which says that similarity is the possession by a thing belonging to one class (jāti), of a number of constituent parts (universals) in common with an object belonging to another class. ${ }^{15}$

An interesting problem is posed by Ratnaśrījñāna's treatment of dissimilarity - he says that Gauḍiya is starkly different to all of these other styles in the way a camel is dissimilar to a cow. This striking comparison is particularly reminiscent of the discussion under NS 2.1.44-48 which has been comprehensively presented in the upamāna-khanda, or 'Chapter on Analogy' of the Tattvacintāmani (TCM) composed by Gangeśa (-upādhyāya) in Mithila in the $14^{\text {th }}$ century. ${ }^{16}$ Gangeśa portrays a discussion between himself and a group

15 bhūyovayava-sāmānya-yogo jāty-antarasya tat. See Bandyopadhyay 1982: $248 \mathrm{ff}$. for a detailed analysis.

16 See Phillips 2012 for an English translation of the upamāna section of the TCM. The camel itself appears in a much earlier discussion of sādriśya in Nyāya, but the context is not dissimilarity but an argument on the very existence of upamāna as a means of valid cognition. In the Nyāyavārtikatātparyațīka (pg. 198ff.) one of Vācaspati Miśra's opponents, giving the example "dhik karabham..." tries to undermine analogical reasoning as a pramāna and forces him to investigate the difference between verbal testimony and analogy — can a Southerner overhearing a Northerner cursing indolent camels (and inadvertently describing their characteristics such as long necks and an affinity for eating thorny plants), then claim to know the meaning of 'camel' and recognise the animal when he travels North? First, says the opponent, if we just consider the sütra, there is no 'similarity' of properties in this example since there are actually no properties being compared at all (na tāvad upamānam sādharmyābhāvāt). 
of opponents, including the 'old' ( $p \bar{u} r v a$ ) Naiyāyikas. Understandably, the cow and the gayal archetype acts as the framework for the consideration of similarity and analogical reasoning. Within the larger discussion on yathä gaur evam gavaya iti, Gangeśa considers, among others, the efficacy of a statement like "a cow is dissimilar to a camel" in the production of knowledge and whether the camel-dissimilarity (karabha-vaidharmya) of a cow implies the cow-dissimilarity (go-vaidharmya) of a camel (TCM pg. 49). Unfortunately, Ratnaśrījñāna himself does not give the question of dissimilarity a substantial amount of attention in his commentary on verse 1.40 but we can deduce that he accepts dissimilarity as a valid instrument of obtaining veridical knowledge (probably through the process of analogical reasoning). ${ }^{17}$ By bringing together cows, gayals and camels in the context of similarity and analogy and emphasising that these are universals (jāti) which can be efficaciously compared for the production of cognition, Ratnaśrījñāna points unambiguously to the discussions directing his reasoning. The archetypes serve as shorthand for the robust philosophical debates that form the underpinnings of the argument on the relationships between the 'ways' of literature.

\section{What is a subtype? On universals, cows, and horses}

It comes as no surprise that in his remarks on $\mathrm{K} \overline{\mathrm{A}} 1.101$, the verse which seems to formally close the theoretical discussion of the mārga-vibhāga,

But even if this situation does lead to valid cognition, the opponent then stipulates that the Southerner achieved this knowledge not through analogy, but first through verbal testimony (śabda), then direct perception (pratyakșa), and finally, inference (anumāna) - ergo, no need for upamāna. Vācaspati's solution is to expand the meaning of sādharmya to indicate not the similarity of particular properties but the similarity of features 'in general' (sādharmya-grahaṇam ca dharma-mātropalakșaṇam). In this sense, then, the camel example does in fact lead to valid cognition and the means is analogical reasoning. Gangeśa also cites this discussion a little later in his treatise (TCM pg. 61ff.).

17 Perhaps calling to mind Udyotakāra's commentary on NS 2.1.44. I thank Nilanjan Das for this reference. 
Ratnaśrījñāna turns his attention to the phrase tad-bhedāh, or the subdivisions of the two main 'ways'. ${ }^{18}$ He puts emphasis on explaining the very concept of 'subdivision' (prabheda) of the two entirely different (prasphuta) modes of composition called Vaidarbha and Gauḍiya into categories which are somehow similar to the two superordinate märgas. The principle that allows us to group these Vaidarbha and Gaudīya subtypes (which cannot be tallied according to Daṇdin) is bheda-sāmānya ${ }^{19}$ - similarity in difference. We are able to identify them as belonging either to one or the other 'way' because they are coherent in their dissimilarity to the subtypes belonging to the opposing mārga.

Ratnaśrījñāna does not follow this analysis to the level of actual practice and does not consider what impact his reflections might have on the composition or reception of a literary text. He is focussed on the methodology of the system proposed by Daṇin and does not explain how a poem composed in a subtype of the Vaidarbha mārga is to be distinguished from one written in a type of Gauḍiya. However, if we take up his reasoning, we should presumably be able to recognise a Vaidarbha type poem on the basis of two factors - its correspondence with the characteristics of Vaidarbha and its divergence with those posited as present in Gauḍiya. ${ }^{20}$

Just as there is an infinite number of things which take universals as their objects (sāmānya-lakșaṇa-nyāstā ānantāhh), such as 'cow' and 'horse' (gavāśva-bhedavat) ${ }^{21}$, in the same way there can be an infinite

18 Sanskrit text in Thakur and Jha 1957: 57 and on SARIT (see note 12).

19 Perhaps Ratnaśrījñāna has in mind a passage on universals (1.137-142) from Dharmakīrti's Pramānavārttika, where the concept of bheda-sāmānya is used to explain how it is possible to cognise a mass (samūha) of particulars (viśeșa) as a single entity. See Dunne 2004: 353ff. for a translation and 106ff. for a study.

20 This brings to mind Dharmakīrti's concept of apoha-cognising through exclusion, i.e. that a 'cow' is cognised as such on account of it not being a 'not cow'. See Keyt 1980: 103ff.

21 The cow and the horse form an archetypal pair in many philosophical discussions, often those related to apoha. 
number of subtypes of the 'ways' of literature, which, according to Ratnaśrījñāna, take the 'universals' Vaidarbha and Gauḍīya as their objects. He then suggests that all poets will inadvertently follow one of the two, main 'ways' however he does not comment on the process of transformation which leads to the 'way' being distorted into an idiosyncratic sub-type.

\section{Conclusions}

Daṇ̣in's approach is pragmatic and based on experience - it is obvious in practice that each poet has an individual style which cannot be perfectly categorised into a neat system. However, Dandin encourages us to accept that there are two coherent methods of composition which are so starkly dissimilar that their comparison may be worthwhile. Importantly, in the introductory verse 1.40 , he does not postulate that these two different modes are in some way superordinate to the other 'ways'. This message is muddled in 1.101 where he notes that the two distinct modes of composition do, in fact, possess sub-types. Yet, even then, these subtypes are not necessarily presented as 'ways' somehow equivalent to Vaidarbha and Gaudīiya.

Ratnaśrījñāna does not seem satisfied with this reasoning and combines the two verses framing the mārga-vibhāga into a cogent theory which, contra Danḍin, identifies Vaidarbha and Gauḍiya as epitomes based on which all other 'ways' are to be construed. Yet, he remains frank about the obscurities of the märga-vibhāga and in closing his commentary on the first chapter of the $\mathrm{K} \overline{\mathrm{A}}$, remarks that the section covered has been like 'stony ground' but that from thereon, things would be much easier. ${ }^{22}$

To make sense of the concept, he imbues Dandin's discussion of 'ways' with an epistemic perspective and creates a methodological

22 matam khila-prāyam ihāsti dandịnah tad-etad atra prakṛtam parisphuțam| itah purastāt samam eva vartate tadatra nāsmābhir abhāvito vidhiḥ \|

(Thakur and Jha 1957: 66) 
template, based on established saāstric principles, which is impervious to the ambiguities of the gunas and the opacity of the entire system of mārgas. In a sense, by placing his investigation on a higher plane of abstraction than the nature of the 'ways' themselves, he succeeds where the empiric model of Vāmana had failed - in creating an academic, rational and defensible schema of literary modes.

\section{References}

\section{Primary sources}

Balasubrahmanyam, J. K. (ed.). 1909. Kāvyālaṃkārasūtravrtti. With the Commentary Kāmadhenu. Srirangam: Sri Vani Vilas Press.

Dimitrov, D. (ed. and transl.). 2002. Mārgavibhāga. Die Unterscheidung der Stilarten. Band 40. Indica et Tibetica. Marburg: Indica et Tibetica Verlag. Drāviḍa, R. Ś. (ed.). 1983. Nyāyavārtikatātparyațīkā. Vol. 1. Benares: Chowkhamba Sanskrit Series Office.

Nyāyasūtra with Vātsyāyana's Bhāṣya. https://sarit.indology.info/vatsyayananyayabhasya.xml?view=div $(27.08 .2020)$.

Rudrața. 1983. Kāvyālaṃkāra. Delhi-Varanasi-Patna: Motilal Banarsidass.

Tarkavāgīśa, Pandit K. N. (ed.). 1897. The Tattvacintāmaṇi by Gañheșa Upādhyāya. Part III. Upamāna Khaṇda. Bibliotheca Indica. Asiatic Society of Bengal, New Series. No. 844. Calcutta: Asiatic Society.

Thakur, A. and U. Jhā (eds). 1957. Kavyalaksana, also known as Kavyadarśa. With commentary called Ratnaśri of Ratnaśrijñana. Darbhanga: Mithila Institute of Post-Graduate Studies and Learning. https://sarit.indology.info/ ratnasritika-dn.xml?view $=\operatorname{div}(27.08 .2020)$.

\section{Secondary sources}

Bandyopadhyay, N. 1982. The Concept of Similarity in Indian Philosophy. In: Journal of Indian Philosophy, 10 (3): 239-275. 
Dimitrov, D. 2016. The Legacy of the Jewel Mind. On the Sanskrit, Pali, and Sinhalese Works by Ratnamati. A Philological Chronicle. Napoli: Università degli studi di Napoli “L'Orientale”, Dipartimento Asia Africa e Mediterraneo.

Dunne, J. D. 2004. Foundations of Dharmakirti's Philosophy. Studies in Indian and Tibetan Buddhism. Boston: Wisdom Publications.

Gerow, E. 1971. A Glossary of Indian Figures of Speech. The Hague-Paris: Mouton. Keyt, C. M. 1980. Dharmakirti's Concept of Svalakșana. Unpublished PhD Thesis, University of Washington. http://hdl.handle.net/1773/5723 (5.05.2019).

Lahiri, P. C. 1937. Concepts of Rīti and Guṇa in Sanskrit Poetics. Dacca: University of Dacca.

McCrea, L. J. 2008. The Teleology of Poetics in Medieval Kashmir. Cambridge, Mass: Harvard University Press. Harvard Oriental Series 17.

Phillips, S. 2012. Epistemology in Classical India: The Knowledge Sources of the Nyayya School. New York: Routledge.

Pollock, S. 2003. Sanskrit Literary Culture from the Inside Out. In: S. Pollock (ed.). Literary Cultures in History. Reconstructions from South Asia. Berkeley: University of California Press: 39-130.

Pollock, S. 2005. Ratnasrijnana. In: R. K. Sharma (ed.). Encyclopedia of Indian Wisdom: Dr. Satya Vrat Shastri Felicitation Volume. Delhi: Bharatiya Vidya Prakashan: 637-643.

Pollock, S. 2006. The Language of the Gods in the World of Men. Sanskrit, Culture, and Power in Premodern India. Berkeley: University of California Press.

Raghavan, V. 1978. Bhoja's Śrngāra Prakāśa. Madras: Punarvasu.

Tubb, G. 1985. Abhinavagupta on Phonetic Texture. In: Journal of the American Oriental Society 105 (3): 567-578. https://doi.org/10.2307/601531.

Tubb, G. 2008. Philosophic Beginnings in Sanskrit Treatises on Poetics. In: W. Slaje (ed.). Sástrārambha: Inquiries into the Preamble in Sanskrit. Weisbaden: Harrassowitz Verlag: 171-182. 